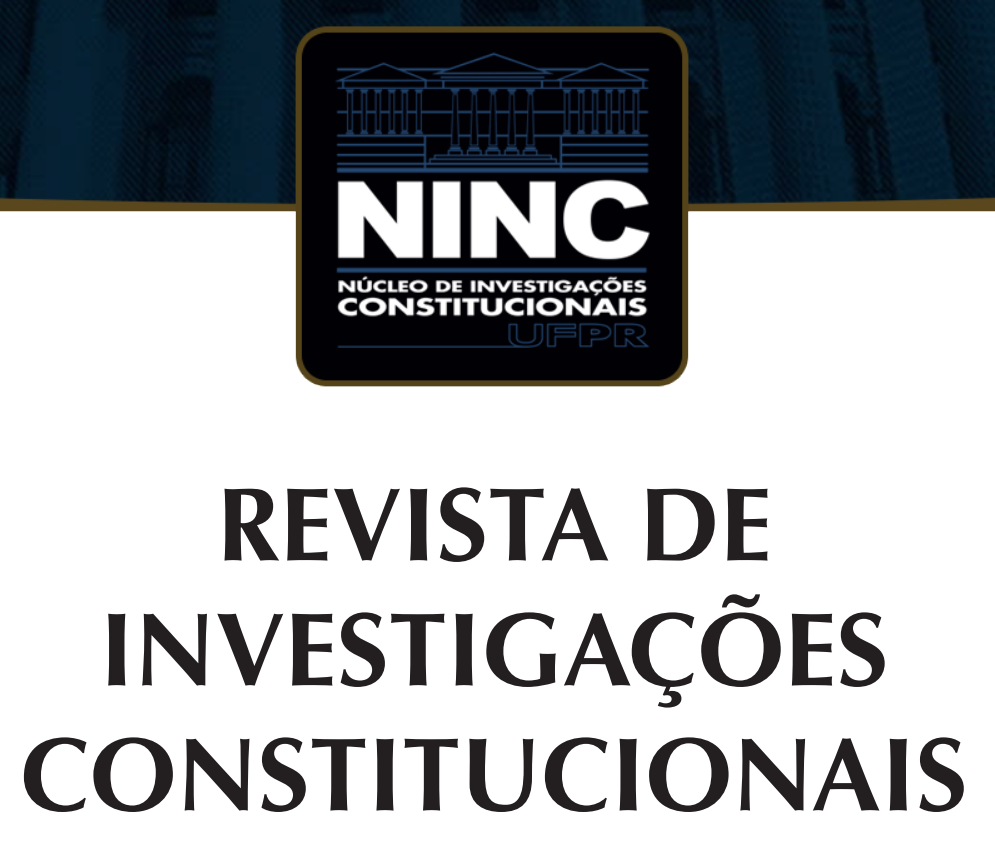

JOURNAL OF CONSTITUTIONAL RESEARCH

vol. 7 | n. 2 | maio/agosto 2020 | ISSN 2359-5639 | Periodicidade quadrimestral Curitiba | Núcleo de Investigações Constitucionais da UFPR | www.ninc.com.br 


\title{
Equality-based arguments for the decriminalization of abortion in Brazil: towards new legal opportunities*
}

\section{Argumentos na chave da igualdade para a descriminalização do aborto no Brasil: rumo a novas oportunidades legais}

\author{
TAÍS SOFIA CUNHA DE BARROS PENTEADO ${ }^{1, * *}$ \\ ' Fundação Getúlio Vargas - FGV/SP (São Paulo, São Paulo, Brasil) \\ tais.penteado@gmail.br \\ https://orcid.org/0000-0003-0329-3681 \\ Recebido/Received: 25.10.2019 / October $25^{\text {th }}, 2019$ \\ Aprovado/Approved: 29.10 .2020 / October $29^{\text {th }}, 2020$
}

Abstract

This article aims to contribute to the abortion debate in Brazil, by looking deeply at how the equality principle is being mobilized by pro-decriminalization actors in the specific context of ADPF 442, the lawsuit in which the constitutionality of the abortion restriction up to the 12th week is challenged before the Brazilian Supreme Court. We map and classify the different formulations of equality arguments presented by the claimant and other relevant actors. We then discuss one of the formulations - the formulation that characterizes abortion as a means of group subordination - in light of the legal opportunity structure available in Brazil. We argue that while this argument faces a challenge posed by the

\section{Resumo}

Este artigo tem o objetivo contribuir para o debate sobre o aborto no Brasil, analisando profundamente como o princípio da igualdade está sendo mobilizado por atores pró-descriminalização no contexto específico da ADPF 442, processo em que a restrição do aborto até $12^{a}$ semana é contestada perante o Supremo Tribunal Federal. Mapeamos e classificamos as diferentes formulações de argumentos de igualdade apresentadas pelo reclamante e outros atores relevantes. Discutimos então uma das formulações - a formulação que caracteriza o aborto como um mecanismo de subordinação de grupo - à luz da estrutura de oportunidades legais disponíveis no Brasil. Argumentamos que, embora esse argumento enfrente um desafio colocado

Como citar esse artigo/How to cite this article: PENTEADO, Taís Sofia Cunha de Barros. Equality-based arguments for the decriminalization of abortion in Brazil: towards new legal opportunities. Revista de Investigações Constitucionais, Curitiba, vol. 7 n. 2, p. 451-472, maio/ago. 2020. DOI: 10.5380/rinc.v7i2.69881.

"This paper was produced with the support of grant \#2019/07715-1, São Paulo Research Foundation (FAPESP). Many thanks to the gentle and constructive comments provided by Camila Gianella, Marta Machado and other colleagues that participated in the group discussion during the LawTransform PhD Course that took place in Bergen, Norway, in August 2019. I had the pleasure to attend this program lead by Siri Gloppen and Camila Gianella and coordinated by Lara Côrtes, both from Chr. Michelsen Institute - CMI, as part of the International Partnerships for Excellent Education and Research (INTPART) programme to which FGV Law School of São Paulo is a partner institution. Also, many thanks to Professor Dimitri Dimoulis, for his usual careful and sharp reading.

** Mestranda em Direito e Desenvolvimento na FGV Direito SP (São Paulo-SP, Brasil), na linha Instituições do Estado Democrático de Direito. E-mail: tais.penteado@gmail.br. 
narrow formulations of the equality principle in general in Brazil, it also opens up a new window for arguing, for being close in formulation to an important equality case ruled by the Supreme Court - ADPF 186, an affirmative action case.

Keywords: abortion; equality-based arguments; anti-subordination; ADPF 442; ADPF 186. pelas formulações restritas do princípio da igualdade que prevalecem no Brasil, ele também abre uma nova janela de oportunidade para argumentar, por ser próximo da formulação de igualdade utilizada pelo Supremo Tribunal Federal na ADPF 186, que envolve cotas raciais para universidades.

Palavras-chave: aborto; argumentos na chave da igualdade; anti-subordinação; ADPF 442; ADPF 186.

\section{CONTENTS}

1. Introduction; 2. Equality-based arguments in the context of ADPF 442; 2.1.Discriminatory treatment between women from different backgrounds; 2.2.Discriminatory treatment between men and women; 2.3. Equality as anti-subordination; $\mathbf{3}$. Idea of equality as anti-subordination without translation into rights discourse; 4. Equality as anti-subordination: limits and potentials; 4.1. The need for a broader formulation of the equality principle; 4.2. The anti-subordination formulation: towards a new window for action; $\mathbf{5}$. Conclusions; $\mathbf{6}$. References.

\section{INTRODUCTION}

The fight for the decriminalization of abortion has been in motion in Brazil since 1970 s $^{1}$, and, since then, pro-choice feminist movements have adopted a myriad of strategies, at first in the legislative and executive arenas and later in the judicial arena, to press this agenda ${ }^{2}$. The drafting of the new Brazilian Constitution in 1988 was a turning point for social movements, as it provided them with the possibility of framing the abortion issue as a matter of constitutional rights and, therefore, of constructing different narratives of injustice ${ }^{3}$.

This new rights-based approach has been a constant in all state's arenas debates about abortion, however, since 2003, due to shifts in political opportunities, the battle over abortion rights in the judicial arena has prevailed ${ }^{4}$.

The first important move was the proposal Argument of Non-Compliance with Fundamental Precept No. 54 ("ADPF 54") before the Brazilian Supreme Court, a

BARSTED, Leila de Andrade Linhares. Legalização e descriminalização do aborto no Brasil: 10 anos de luta feminista. Revista Estudos Feministas. Florianópolis, vol. 0, n. 0, p. 104-130, Jan. 1, 1992.

2 MACHADO, Marta; MACIEL, Debora. The Battle Over Abortion Rights in Brazil's State Arenas, 1995-2006. Health and Human Rights Journal. Boston, vol. 19, n. 1, Jun. 2, 2017. Available at: <https://www.hhrjournal. org/2017/06/the-battle-over-abortion-rights-in-brazils-state-arenas-1995-2006/>. Retrieved Oct. 25, 2019.

3 MACHADO, Marta Rodriguez de Assis; COOK, Rebecca J. Constitutionalizing abortion in Brazil. Revista de Investigações Constitucionais, Curitiba, vol. 5, n. 3, p. 185-231, set./dez. 2018. Available at: <https://revistas. ufpr.br/rinc/article/view/60973/37524 . Retrieved Oct. 25, 2019.

4 MACHADO, Marta; MACIEL, Debora. The Battle Over Abortion Rights in Brazil's State Arenas, 1995-2006. Health and Human Rights Journal. Boston, vol. 19, n. 1, Jun. 2, 2017. Available at: <https://www.hhrjournal. org/2017/06/the-battle-over-abortion-rights-in-brazils-state-arenas-1995-2006/>. Retrieved Oct. 25, 2019. 
challenge to the prohibition of abortion in cases of fetal anencephaly. The strategic litigation in this case led to the inclusion of a new excuse under law for the performance of abortion in the Brazilian Penal Code, which previously provided for the permission to perform abortion only in cases of danger to the woman's health and of pregnancy resulting from rape ${ }^{5}$.

The results of ADPF 54 are controversial ${ }^{6}$, however, the lawsuit did start off the court centered abortion debate, which culminated in the proposal of ADPF $442^{7}$. The thesis defended in ADPF 442 is that the criminalization of abortion until the 12th week of pregnancy violates the fundamental precepts "of human dignity, citizenship, non-discrimination, inviolability of life, freedom, equality, prohibition of inhuman or degrading torture or treatment, health and family planning of women, adolescents and girls"8.

In March 2018, the rapporteur of the case, Justice Rosa Weber, convened a Public Hearing on the topic, which was held on August 3 and 6, 2018, with the participation of relevant sectors of civil society. However, to date, the trial has not been ruled. It is unclear what motivated the slowdown in the ADPF 422 trial, but it would not be unreasonable to imagine that it may be a way to prevent the moods and political climate that followed the 2018 elections from pushing the STF to one side or another - after all, the issue of abortion is of unparalleled political sensitivity.

The slowdown in the trial is negative, since it holds such an important issue and with such damaging consequences for women, especially the most vulnerable without resolution. However, it is possible to take this gap as an opportunity to broaden the reflections on the theme, and that is precisely what the present paper intends to do.

The rights discourse has been at the core of abortion disputes for decades and there are a lot of different rights and principles that can be used in order to advance the decriminalization claim ${ }^{9}$. This article looks deeply at how the equality principle is

\footnotetext{
5 See the Brazilian Penal Code: "Art. 128 - Medical abortion is not punished: I - if there is no other way to save the life of the pregnant woman and II - if the pregnancy results from rape and abortion is preceded by the consent of the pregnant woman or, when incapable, of her legal representative."(BRAZIL. Decreto-lei n. 2.848, de 7 de dezembro de 1940. Código Penal. Diário Oficial da União, Rio de Janeiro, RJ, Dec. 7, 1940. Available at:<http://www.planalto.gov.br/ccivil_03/decreto-lei/Del2848compilado.htm>.Accessed on: 19 Mar. 2018).

6 See, for instance, MACHADO, Marta Rodriguez de Assis; COOK, Rebecca J. Constitutionalizing abortion in Brazil. Revista de Investigações Constitucionais, Curitiba, vol. 5, n. 3, p. 185-231, set./dez. 2018. DOI: 10.5380/ rinc.v5i3.60973. Available at: <https://revistas.ufpr.br/rinc/article/view/60973/37524>. Also, PENTEADO, Taís. The abortion jurisprudence in Brazil: An analysis of ADPF 54 from feminist equality-based perspectives. International Journal of Constitutional Law, Forthcoming. The papers approach the decision from different perspectives.

7 The lawsuit was brought by PSOL - Partido Socialismo e Liberdade.

8 See the 1988 Brazilian Federal Constitution, art. $1^{\text {th }}$, I e II; art. $3^{\text {th }}$, IV; art. $5^{\text {th }} ;$ art. $5^{\text {th }}$, I; art. $5^{\text {th, }}$ III; art. $6^{\text {th }}$; art. 196 and art. 226, $\S 7^{\text {th }}$.

9 SIERRA, Isabel Cristina Jaramillo. Introducción. In: BERGALLO, Paola; SIERRA, Isabel Cristina Jaramillo; VAGGIONE, Juan Marcos. El aborto em América Latina. Estrategias jurídicas para luchar por su legalización y
} 
being mobilized by pro-decriminalization actors in the specific context of ADPF $442^{10}$ and then reflects about this principle in the context of the abortion dispute, in light of the concept of legal opportunities.

Our point of departure was to conduct documental analysis of both the Initial Petition presented by the claimant of the lawsuit and the memorials presented by pro-decriminalization actors in the context of the Public Hearings promoted by the Supreme Court on the matter, where we were able to map the different formulations of equality-based arguments by the different actors ${ }^{11}$.

For the purposes of this article, we had the particular interest to look at how the right to equality had been mobilized in the context of ADPF 442. Initially, we intended to look only at the Initial Petition, but this would pose serious limitations to our assessment of how equality arguments in case of abortion are being mobilized broadly speaking. Simply because the claimant is one of the actors in the debate. We then decided to look also at how pro-decriminalization advocates have formulated equality arguments in the context of the Public Hearings ${ }^{12}$.

In Brazil, both the law ${ }^{13}$ concerning constitutional actions such as ADPF 442 and the internal regiment of the Supreme Court allows for Justices to ask for a Public Hearing

enfrentar las resistencias conservadoras. Buenos Aires: Siglo XXI Editores Argentina, 2018. p. 18.

10 We acknowledge the existence of other interesting arguments or ways of talking about abortion, such as autonomy-based and health-based approaches, however, here we are interested to see how the equality principle is being played. Also, we acknowledge the importance of looking also to how the advocates of different positions regar abortion are talking about abortion. However, for the purpose of this paper we will attain to pro-decriminalization advocates.

11 PSOL, the claimant of ADPF 442 and the entities National Academy of Medicine, ANIS - Bioethics, Human Rights and Gender Institute, Brazilian Anthropology Association, Catholic Women for the Right to Choose, CEBRAP - Brazilian Center of Analysis and Planning, CEMICAMP - Campinas Center for Research in Reproductive Health, Center for Reproductive Rights, CLACAI - Latin-American Consortium against unsafe abortion, UFMG Human Rights Clinic, UERJ Clinic, CFEMEA - Feminist Center of studies and Advice and others, CONECTAS Human Rights, Federal Psychology Counsel, National Human Rights Counsel, Federal Government Public Defenders, DPE/RJ - Public Defenders from the State of Rio de Janeiro, FEBRASGO - Federation of Gynecology and Obstetrics Associations, Fiocruz - Fernandes Figueira National Institute of Women's, Child and Adolescent Health of the Oswaldo Cruz Foundation, Human Rights Watch, IBCCRIM - Brazilian Institute of Criminal Sciences, Baresi Institute, Institute of Bio Law and Bioethics, Brazilian Institute of Private Law, Institute of Religion Studies, International Women's Health Coalition, IPAS -Pernambuco's Institute of Assistance and Health, Melania Amorim, Ministry of Health, NPJDH-USP - USP Human Rights Legal Practice Center, NUDEM - Specialized Center for the Defense and Promotion of Women's Rights and FGV SP Clinic, SBPC - Brazilian Society for the Progress of Science, Brazilian Bioethical Society, UJUCASP - Union of Catholic Jurists of São Paulo, Women on waves. Free translation of the entities' names.

12 From now one we will refer to the Initial Petition and memorials in the footnotes, in order to maintain the fluidity of the text. All documents can be found online, in Portuguese, in the Brazilian Supreme Court Case, http://portal.stf.jus.br > Search by Class and Number > ADPF $442>$ Files > Documents 432 to 482.

13 BRAZIL. Lei n. 9.868, of November 10, 1999. Dispõe sobre o processo e julgamento da ação direta de inconstitucionalidade e da ação declaratória de constitucionalidade perante o Supremo Tribunal Federal. Diário Oficial da União, Brasília, DF, Nov. 10, 1999. Available at: <http://www.planalto.gov.br/ccivil_03/leis/l9868. htm >.Accessed: 20 mar. 2018.; BRAZIL. Lei n. 9.882, of December 3, 1999. Dispõe sobre o processo e julgamento da argüição de descumprimento de preceito fundamental, nos termos do $\S 1^{\circ}$ do art. 102 da Constituição 
when presented with hard cases regarding society's plural visions on the matter. In this context, the Public Hearing would not only provide the court with significant information, but also "compensate for democratic deficits in an unelected body capable of invalidating majority decisions"14.

The regulations pertaining Public Hearings provide, generally, that the Justice reporting the case can convene a Public Hearing when in need of clarifications about the matter by experts on the issue. Because of that, in June 4 2018, Justice Rosa Weber presented a monocratic decision in which she stated that

The discussion now under consideration and deliberation of this Federal Supreme Court, in fact, is one of the most sensitive and sensitive legal issues, while involving ethical, moral, religious, public health and protection of individual fundamental rights. Comparative jurisdictional experience demonstrates this reality. Thus, the complexity of the constitutional controversy, as well as the role of constructor of public reason that legitimizes the performance of constitutional jurisdiction in the protection of fundamental rights, justifies the convening of public hearing, as a necessary procedural technique, the content of art. 6, §1, of Law no. 9.882 / 99, and of arts. 13, XVII, and 154, III, sole paragraph, both of the RISTF.

Our mapping of the ways in which equality arguments were formulated was made through documental analysis of Initial Petition of the lawsuit and the memorials presented in the Public Hearing context ${ }^{15}$. We acknowledge that other relevant actors

Federal. Diário Oficial da União, Brasília, DF, Dec. 3, 1999. Available at:<http://www.planalto.gov.br/ccivil_03/ Leis/L9882.htm>. Accessed: 20 mar. 2018.

14 LEAL, Fernando; HERDY, Rachel; MASSADAS, Julia. Uma década de audiências públicas no Supremo Tribunal Federal (2007-2017). Revista de Investigações Constitucionais, Curitiba, vol.5, n.1, p. 334, Jan./Apr. 2018. Available at: <https://revistas.ufpr.br/rinc/article/view/56328>. Retrieved Oct. 25, 2019.

15 The entities that presented memorials, including advocates for both sides are: National Academy of Medicine, ANAJURES - National Evangelic Jurists Association, ANIS - Bioethics, Human Rights and Gender Institute, Brazilian Anthropology Association, ADFAS - Family and succession Law Association, Pro-Life and Pro-Family Association, Catholic Women for the Right to Choose, CEBRAP - Brazilian Center of Analysis and Planning, CEMICAMP - Campinas Center for Research in Reproductive Health, Center for Reproductive Rights, CERVI - Center for Life restructuring, CLACAI - Latin-American Consortium against unsafe abortion, UFMG Human Rights Clinic, UERJ Clinic, CFEMEA - Feminist Center of studies and Advice and others, CONAL- The National Council of the Laity of Brazil in the Archdiocese of Aracaju-SE, CONECTAS Human Rights, Israeli Confederation of Brazil, Federal Psychology Counsel, National Human Rights Counsel, Brazilian Baptist Convention, God's Assembly General Convention, Federal Government Public Defenders, DPE/RJ - Public Defenders from the State of Rio de Janeiro, State of Sergipe, FAMBRAS - Brazilian Muslim Federation, FEBRASGO - Federation of Gynecology and Obstetrics Associations, Brazilian Spiritism Federation, FENACAB - National Federation of Afro Brazilian Worship, Fiocruz - Fernandes Figueira National Institute of Women's, Child and Adolescent Health of the Oswaldo Cruz Foundation, Parliamentary Front, Human Rights Watch, IBCCRIM - Brazilian Institute of Criminal Sciences, Baresi Institute, Institute of Bio Law and Bioethics, Brazilian Institute of Private Law, Institute of Religion Studies, Institute of Government Policy of Brazil, International Women's Health Coalition, IPAS -Pernambuco's Institute of Assistance and Health, Janaina Paschoal, Melania Amorim, Ministry of Health, National Citizenship Movement for Life, NPJDH-USP - USP Human Rights Legal Practice Center, NUDEM - Specialized Center for the Defense and Promotion of Women's Rights and FGV SP Clinic, Raphael Câmara, SBPC - Brazilian Society for the 
such as doctrinal authors and social movements that have not participated in the Public Hearing were left out of the analysis.

In Sections 2 and 3, we present the results of our mapping. We have found out that the principle of equality is used in three different ways: first, to make the argument that the criminalization of abortion leads to discriminatory treatment between women from different backgrounds. Secondly, to argue that the criminalization of abortion discriminates between men and women, to the extent that it imposes a penalty to women that has no equivalent for men. Thirdly, to advance the argument that abortion criminalization stems from and perpetuates women subordinated status in society-or, as we call it, an argument of equality as anti-subordination. The mapping has also shown that the idea that the abortion criminalization is a matter of maintenance of subordination is present in a significant number of manifestations - the Initial Petition included - without necessarily being translated into rights discourse.

After this first descriptive moment, we lay some comments on the limits and potentials of the formulation of equality as anti-subordination in the case of abortion in view available legal stock in the Brazilian legal opportunity structure. The legal stock is usually seen as constitutionally entrenched rights that allow for actors to translate their political claims into legal claims ${ }^{16}$. We propose a broader conception that encompasses also the existing conceptualizations of the principles and the case law established by the courts. This comments are developed in Section 4.

In what regards the limits, we argue that the most common conceptualization of the equality principle in Brazil is not able to deal with cases such as the abortion issue. That because it can only deal with difference of treatment between groups and not with situations in which the practice is not necessarily discriminatory, but perpetuates subordination of a determined group nonetheless. We claim that the non-translation of ideas of equality of anti-subordination into principled arguments could be an indicative of this limit posed by a narrow understanding of equality.

In what regards the potentials, we argue that the formulation of an equality argument in the model of anti-subordination could be a strong way of arguing before the Supreme Court. That, because the Supreme Court have decided an important case in the basis of an anti-subordination approach: the affirmative action cases related to racial quotas for universities. If one looks of abortion criminalization as a difference of treatment between groups issue, it is not possible to see how similar the matter is to affirmative action cases. However, we argue the two issues can be seen as similar if seen through the anti-subordination perspective, and, therefore, this line of case law could

Progress of Science, Brazilian Bioethical Society, UJUCASP - Union of Catholic Jurists of São Paulo, Women on waves. Free translation of the entities' names.

16 ANDERSEN, Ellen Ann. Out of the Closets and Into the Courts: Legal Opportunity Structure and Gay Rights Litigation. Ann Arbor: University of Michigan Press, 2005. p. 1-16. 
open a new path for argumentation in terms of legal opportunities. We conclude in Section 5 .

\section{EQUALITY-BASED ARGUMENTS IN THE CONTEXT OF ADPF 442}

We have mapped three different ways in which the equality principle has been mobilized by the actors: first, to make the argument that the criminalization of abortion leads to discriminatory treatment between women from different backgrounds. Secondly, to argue that the criminalization of abortion discriminates between men and women, to the extent that it imposes a penalty to women that has no equivalent for men. Thirdly, to advance the argument that abortion criminalization stems from and perpetuates women subordinated status in Brazil.

\subsection{Discriminatory treatment between women from different back- grounds}

The first formulation of abortion criminalization as a violation of equality appears in the form of an argument of different treatment between women from different backgrounds. According to this argument, the criminalization of abortion violates equality to the extent that different women end up having different access to rights such as life, health and reproductive rights. This argument can be found in the following passages extracted from both the Initial Petition and from some of the memorials presented in the context of the Public Hearing:

"Although all women are potentially subject to the criminal prohibition of abortion, criminalization disproportionately affects poor black and indigenous women with low education who live far from urban centers, where methods of abortion are more unsafe, than those used by women with greater access to information and economic power, resulting in a serious affront to the principle of non-discrimination"17.

"Due to the selectivity of the penal system, it is also the most vulnerable women who are directly subject to punitive action by the state, in the form of complaints by health professionals, exposure of medical intimacy, harassment of the media, police investigations, provisional arrests and criminal proceedings"18.

"Decriminalization of abortion (...) would accommodate gender-based reproductive health differences in women and ensure women's substantive equality (...) Human rights

\footnotetext{
17 Initial Petition, p. 8.

18 Initital Petition, p. 9.
} 
authorities therefore support decriminalization during the first twelve weeks of pregnancy to ensure that women exercise the same right to the right to health by allowing equal access to safe abortion for all women. ${ }^{19 \prime \prime}$

"(...) equality affects the issue also under the economic and racial perspective. As noted in this memorial, it is poor and black women who have their rights, including health and life, most affected by the criminalization of abortion. They are subject to more unsafe procedures and are still at greater risk of criminal prosecution. ${ }^{20 \prime \prime}$

"Recognition of the constitutional right to voluntary termination of pregnancy is still the only way to ensure safe abortion, preserving the equality among women of different social classes ${ }^{21 "}(p .4)$

"There is a direct affront to the very constitutional principle of equality as non-discrimination (art. 3, clause IV), since the Brazilian reality presents a flagrant situation of intersectional discrimination, which exposes black women more acutely to death and other consequences of unsafe abortion procedures. ${ }^{22 "}$

"On non-discrimination and equality (...) Even when clandestine abortion can be performed in relatively safe and hygienic places, it can be financially inaccessible to women in the most vulnerable situations. ${ }^{23 \prime \prime}$

\subsection{Discriminatory treatment between men and women}

The second formulation argues that the criminalization of abortion violates equality to the extent that it treats men and women differently. The criminalization imposes a penalty to women that does not have a correspondence to penalties imposed to men and, therefore, deprive women from the equal access to life, health and reproductive rights, among others. This argument can be found in the following passages extracted from both the Initial Petition and from some of the memorials presented in the context of the Public Hearing:

\footnotetext{
CLACAI memorial, p. 5.

UERJ Clinic memorial, p. 12.

National Human Rights Counsel memorial, p. 4.

DPE/RJ - Public Defenders from the State of Rio de Janeiro memorial, p. 7.

IPAS memorial, p. 20.
} 
"The criminalization of abortion also violates the principle of gender equality, deriving from the fundamental right to equality (SC, art. 5, caput) and the Republic's fundamental objective of non-discrimination based on sex (SC, art. 3, item IV), as it imposes on women more serious conditions, even dangerous to their lives and health, for making reproductive decisions that are disproportionate compared to the conditions for men to make the same decisions, which are not subjected to criminalization. and the consequences of penal coercion on the conditions for exercising their rights to a dignified and citizen life $e^{\prime 24}$.

"Decriminalization of abortion serves the interest of women in the equal exercise of rights related to dignity. Such rights include the right to integrity, privacy, freedom, security and freedom from torture, inhuman and degrading treatment, including freedom from violence, and, for example, the egalitarian exercise of their right of conscience (...) In order to fulfill their obligations to guarantee the substantive equality of women, states must treat different cases according to their gender-specific differences in reproduction ${ }^{25}$."

"Gender equality, in the first place, requires consideration of the biological differences between women and men, bearing in mind, therefore, that since it is an event that takes place in a woman's body, she must make the decision whether or not to continue a preg$\operatorname{nancy}(. . .)^{26 \prime \prime}$.

"Criminalization is discriminatory because men are not penalized and should not put their lives and freedom at risk in accessing the medical interventions they need. ${ }^{27 "}$

"Similarly, the imposition on women of pregnancy violates the constitutional principle of equality between men and women. There is no imposition on a man that affects his body capable of approaching what is imposed on a woman: maintaining a pregnancy she does not want".28

\footnotetext{
Initital Petition, p. 12.

UFMG Human Rights Clinic memorial, p. 5.

UERJ Clinic memorial, p. 11.

Human Rights Watch memorial, p. 13.

28 Institute of Bio Law and Bioethics memorial, p.19.
} 
"Criminalization of abortion as gender discrimination and violence (...) In general, it is the woman who submits to the risks of a pregnancy. It is the woman who risks the even common mishaps of pregnancy such as diabetes, eclampsia, thrombosis (... $)^{29 \prime \prime}(p .13)$

"Criminalization of abortion discriminates against women on the grounds of sex because, although both sexes participate in unplanned pregnancies, only women are penalized $^{30 \prime \prime}$.

\subsection{Equality as anti-subordination}

The third way of characterizing the criminalization of abortion as an equality issue comes in the form of an anti-subordination argument. This argument is built from the idea that the criminalization of abortion stems from certain views about women's lives and roles in society and that it perpetuates these very social roles, through concrete consequences on the lives of women, who are trapped into compulsory motherhood, or through the symbolic perpetuation of the social roles that inform the norm in the first place, through stigmatization.

Broadly speaking, the prohibition of abortion is seen as the result, reflection and reproducer of gender asymmetries existing in society and, in this context, the decriminalization would be a way of trying to overcome those power asymmetries. For purposes of distinguishing this particular approach, we will call it, from now on, the equality as anti-subordination argument. This formulation can be found in the following passages:

"Still in the light of gender equality, the stereotypes that bind women to motherhood must be broken, as if the latter were a laudable evolution of the feminine condition, to be accepted with resignation by all of them ${ }^{31 "}$.

"Thus, the historical asymmetries of gender, race and social class in the country are reinforced, deepening a scenario of unfair and disproportionate social inequality to the detriment of the poorest women and girls, which invariably are the only ones that end up being criminalized $(\ldots)^{\prime \prime 32}$.

"It is the woman who supports the pregnancy in her body and, culturally, most of the time, she is responsible for raising the unwanted child (...) motherhood is romanticized

29 Brazilian Institute of Private Law memorial, p. 13.

30 IPAS memorial, p. 20.

31 UERJ Clinic memorial memorial, p. 11.

32 National Human Rights Counsel memorial, p. 5. 
as redemptive and necessary to experience female one who does not wish to be a mother is considered psychologically disturbed, selfish or perverse ${ }^{\prime \prime 33}$.

"The secularity of the state is fundamental for guaranteeing the right to equality in all its aspects, and especially for gender equality (...) It is ecclesiastical patriarchy that wants to make women believe that they become murderers when they decide to discontinue their pregnancy"134.

"The imposition of pregnancy and motherhood (...) confirms the division of labor and the social roles to which women and men are differently subjected. This ultimately exacerbates the cycles of socioeconomic inequality to which poor and peripheral women are subjected. Criminalization is also intrinsically related to the social marginalization generated by the stigma surrounding abortion. ${ }^{35 "}$

\section{IDEA OF EQUALITY AS ANTI-SUBORDINATION WITHOUT TRANSLATION INTO RIGHTS DISCOURSE}

Another interesting feature that came out in our mapping is the fact that, although come actors did not formulate an equality as anti-subordination argument, they did advance the ideas that lay on the basis of such arguments. In other words, the idea that the abortion prohibition is produced by and reaffirms ideals about women's roles and their material subordinate condition appears in the documents, but without being translated into rights discourse. These ideas can be found in the following passages extracted from the memorials presented in the context of the Public Hearing:

"Stereotypes are permanent ways of updating gender inequalities and patriarchy. According to Rebecca Cook, "In the gender stereotype, women's individual needs, treated according to the woman category, are ignored. ${ }^{36 "}$

Being treated as the generic category "woman" is only a sexed figuration of the generic category man, ignoring particularities of women of reproductive age, particularly the most vulnerable. By the generic but nonexistent woman category, gender stereotypes create expectations of destiny for women, such as reproduction, compulsory motherhood, or even heterosexuality. Women outside these stereotypical expectations

33 Brazilian Institute of Private Law memorial, p. 12.

34 Institute of Religion Studies memorial p.2, p. 6.

35 NPJDH-USP - USP Human Rights Legal Practice Center memorial, p. 16.

36 Initial Petition memorial, p. 42. 
in the name of a 'female nature' are victims of serious rights violations and even cruel, inhuman and degrading treatment. ${ }^{37 "}$

"In the case of abortion, [Stigma] is produced by a complex of ideas produced by and reaffirmed by religion, morals and law, which imposes on women the expectation that all pregnancies should result in childbirth and that all women must be mothers (...) and that there should be a feminine nature perpetuated by la $w^{38 "}$.

"Legalization of abortion accomplishes a fundamental ideological and political break in political and social thought, logic and practice in relation to moral conservatism that confines women in the sole role of mothers and wives, degrading motherhood because it understands it as a biological and not as an ethical choice (... $)^{39 \prime \prime}$.

"Criminalization strengthens the stigmatization and marginalization of women who opt for voluntary termination of pregnancy (...) This stigma stems precipitously from the social construction that the desire for motherhood would be intrinsic to "being a woman"40.

"The criminalization of abortion reinforces the stigma of women who have chosen such a path, diminishing their freedom of choice regarding their role in society and imputing to them compulsory motherhood ${ }^{41 "}$.

"The expected normality for the woman is the passive exercise of the roles of mother, wife, honest, subordinate and not questioning. In this sense, the woman who incurs deviation from these social standards must receive the social punishment, and if this punishment fails, she must suffer the weight of the state arm that reproduces in her normative body the structured social values ${ }^{42}$."

"Recognizing women's individual needs and specific to vulnerability markers such as race, class, sexual orientation, regionality, by guaranteeing them the conditions for

37 Initial Petition memorial, p. 42

38 Brazilian Anthropology Association memorial, p. 3.

39 Catholic women for the right to choose memorial, p. 4.

40 UFMG Human Rights Clinic memorial, p. 11.

${ }^{41}$ CFEMEA memorial, p. 11.

42 Federal Psychology Counsel, p. 10. 
decision-making at the reproductive level, is a possibility to resist the perpetuation of gender stereotypes that violate the dignity of all women"133.

"The criminalization of abortion is linked to the social control of women, a control that is not restricted to preventing only the power of decision, but also to determine about her body, her will and control her place in the social order and also perpetuate pain, suffering and death of the dominated classes ${ }^{44 "}$.

\section{EQUALITY AS ANTI-SUBORDINATION: LIMITS AND POTEN- TIALS}

Because of the shift to courts, socio-legal scholarship has turned its attention to the analysis of legal opportunities structures ${ }^{45}$, which are those structures, pertaining to the legal system, that allow or constrain the possibility of social actors to reach for courts for social change. These legal opportunities structures are often seen as involving three different dimensions: (i) the legal stock available; (ii) the availability of access to the judiciary and (iii) the availability of socio-economic resources for litigation ${ }^{46}$.

When actors such as the ADPF 442 claimant and the other actors who participated in the Public Hearings claim that the abortion criminalization violates equality, they are playing within constraints and possibilities imposed by legal stock.

In this section, we discuss the equality arguments presented in light of the limits and potentials presented by the legal stock available in Brazil. We discuss all the three variations in some extent, but we focus on equality as anti-subordination, for we believe it to be not only a sophisticated way of talking about abortion, which is widely recognized as a strong formulation ${ }^{47}$ and, as will be shown, it might be a strong argument considering the case law of the Brazilian Supreme Court.

\footnotetext{
$43 \quad$ IBCCRIM memorial, p. 12.

44 IBCCRIM memorial, p. 9.
}

45 CASE, Rhonda Evans; TERRI, Givens. Re-engineering Legal Opportunity Structures in the European Union? The Starting Line Group and the Politics of the Racial Equality Directive. Journal of Common Market Studies, [s.I.], vol. 48, n. 2., p. 221-241, mar. 2010.

46 See, e.g., HILSON, Chris "New Social Movements: The Role of Legal Opportunity". Journal of European Public Policy, [s.I.], vol. 9, n.2, p. 238-255, 2002; ANDERSEN, Ellen Ann. Out of the Closets and Into the Courts: Legal Opportunity Structure and Gay Rights Litigation. Ann Arbor: University of Michigan Press, 2005. p. 15.; CASE, Rhonda Evans; TERRI, Givens. Re-engineering Legal Opportunity Structures in the European Union? The Starting Line Group and the Politics of the Racial Equality Directive. Journal of Common Market Studies, [s.I.], vol. 48, n. 2., p. 221-241, mar. 2010.

47 See, e.g, SIEGEL, Reva B. Reasoning from the body: a historical perspective on abortion regulation and questions of equal protection. Stanford Law Review, Palo Alto, vol. 44, n.2, p. 261-382, jan. 1992; SIEGEL, Reva B. Sex equality Arguments for Reproductive Rights: Their Critical Basis and Evolving Constitutional Expression. Emory Law Journal, vol. 56, n. 4, p. 815-842, 2007; SIEGEL, Neil S.; SIEGEL, Reva B. Equality Arguments for Abortion Rights. UCLA Law Review Discourse, [s.I], vol. 160, n. 60, p. 160-170, 2013; TRIBE, Laurence H. American 


\subsection{The need for a broader formulation of the equality principle}

One very important feature of legal stock in what regards demands for social change is the availability of justiciable legal rights. Constitutionally entrenched rights allow actors to frame political demands in rights-based legal claims ${ }^{48}$. In Brazil, for instance, if we consider only the provision of rights in the Constitution, social actors would have plenty of courses of action to try to advance a decriminalizing agenda.

One must recognize, however, that principles in their abstract form account for little. Principles are open-ended mandates that require meaning to be conferred to them by those operating it. Therefore, when thinking about legal stock, it is necessary to keep in mind what principle operators - such as legal scholars, advocates, adjudicators - have in mind about the referred principle content.

Applying this discussion to the case at hand, in Brazil, the equality as anti-subordination faces a challenged posed by how the principle of equality is generally understood. The equality principle is often presented as formal equality (meaning: treating equals alike) or material equality (meaning: treating different differently in order to achieve equality) ${ }^{49}$. For instance, the arguments that characterize the criminalization of abortion as discrimination between groups fall in those categories ${ }^{50}$.

If one says that women from different backgrounds have different access to abortion and that this leads to different access to health and reproductive rights, one is basically saying that women from different backgrounds are equals and should be

Constitutional Law. 2. ed. [s.l.]: Foundation Press, 1988; GINSBURG, Ruth Bader. Some thoughts on Autonomy and Equality in Relation to Roe v. Wade. North Carolina Law Review, Chapel Hill, vol. 63, n. 2, p. 375-386, 1985; LAW, Sylvia A. Rethinking Sex and the Constitution. University of Pennsylvania Law Review, Filadelfia, vol. 132, p. 132, 1984; MACKINNON, Catharine, Abortion: On Public and Private. In: MACKINNON, Catharine. Toward a Feminist Theory of the State. Cambridge: Harvard University Press, 1989. p. 45; MACKINNON, Catharine. Reflections on Sex Equality Under Law. Yale Law Journal, New Haven, vol. 100, n. 4, p. 1282, 1991; BALKIN Jack M. What Roe v. Wade Should Have Said: The Nation's Top Legal Experts Rewrite America's Most Controversial Decision. New York: University Press, 2005, p. 31; BURRIS, Scott. Stigma and the law. The Lancet, [s.I.],vol. 367, n. 9509, p. 529-531, 2006; COOK, Rebecca J. Stigmatized Meanings of Criminal Abortion Law. In: COOK, Rebecca J.; ERDMAN, Joanna N.; DICKENS, Bernard M. Abortion Law in Transnational Perspective. Cases and controversies. Filadelfia: Penn Press, 2014. p. 347; KARST, Kenneth L. The Supreme Court, 1976 Term Foreword: Equal Citizenship Under Fourteenth Amendment. Harvard Law Review, vol. 91, n. 1, p. 57-59, 1977.

48 CASE, Rhonda Evans; TERRI, Givens. Re-engineering Legal Opportunity Structures in the European Union? The Starting Line Group and the Politics of the Racial Equality Directive. Journal of Common Market Studies, [s.I.], vol. 48, n. 2., p. 221-241, mar. 2010.

49 See, e.g., ROCHA, Carmen Lúcia Antunes. Ação afirmativa: o conteúdo democrático do princípio da igualdade jurídica. Revista de Informação Legislativa, Brasília, vol. 33, n. 131, jul./set. 1996; SARLET, Ingo Wolfgang. A eficácia dos direitos fundamentais: uma teoria geral dos direitos fundamentais na perspectiva constitucional. 10. ed. Porto Alegre: Livraria do Advogado Editora, 2011; SARMENTO, Daniel. Livres e iguais: estudos de direito constitucional. 2. ed. Rio de Janeiro: Lumen Juris, 2010; SILVA, José Afonso da. Curso de direito constitucional positivo. 32 ed. São Paulo: Malheiros, 2009.

50 MOREIRA, Adilson José. Pensando como um negro: ensaio de hermenêutica jurídica. Revista de Direito Brasileira, São Paulo, v. 18, n. 7, p. 393-421, set./dez. 2017. have advanced a broader conceptualization of equality, one that goes beyond the rational relation between means and ends and that promotes the equality of status between groups, p. 253. 
treated alike and, for that to happen, abortion should be decriminalized. This is basically a formal equality argument, that states that equals are being treated differently for features, such as race and social background, that should not be reasons for different access to rights. On the other hand, if one argues that women and men's bodies are different, and, therefore equality demands that they be treated differently and that this involves providing abortion rights, one is making a material equality argument.

Diversely, formulating an argument of equality as anti-subordination on abortion demands a broader conceptualization of what can be understood as an equality issue. One that acknowledges that equality demands not only the overcoming of different treatment, but also overcoming structural oppressions that lead to subordinate status of some groups in society ${ }^{51}$. In other words, a conception that shifts from the focus on the difference of treatment, to a conception that "directly considers the impact of state action on the citizens affected by it" ${ }^{\prime 2}$.

The abortion criminalization, in this sense, is seen as an action that perpetuates women's subordinate status in many ways. One of the ways is by means of stereotyping, or, by symbolically reiterating roles socially attributed to women ${ }^{53}$, like some of the actors analyzed above have put it. Another way is by imposing concrete consequences to the lives of real women. In an unequal world, where the responsibilities related to parenting are asymmetrically attributed to women, motherhood generates serious disadvantages in the educational, professional, political and personal realms ${ }^{54}$. A third way is by confining women - especially those most vulnerable - to the realm of reproduction and, consequently keeping them away from the production of knowledge, values and even laws ${ }^{55}$.

Stating that the criminalization of abortion is the result, reflection and reproducer of gender asymmetries existing in society arises from the broader understanding the distribution of power between men and women is asymmetric in the society in

\footnotetext{
51 MACKINNON, Catharine. Difference and dominance: on sex discrimination. In: MACKINNON, Catharine. Feminism Unmodified: Discourses on Life and Law. Cambridge: Harvard University Press, 1987. p. 32; MACKINNON, Catharine. Reflections on Sex Equality Under Law. Yale Law Journal, New Haven, vol. 100, n. 4, p. 1282, 1991.

52 SIEGEL, Reva B. Reasoning from the body: a historical perspective on abortion regulation and questions of equal protection. Stanford Law Review, Palo Alto, vol. 44, n.2, p. 344, jan. 1992.

53 COOK, Rebecca J. Stigmatized Meanings of Criminal Abortion Law. In: COOK, Rebecca J.; ERDMAN, Joanna N.; DICKENS, Bernard M. Abortion Law in Transnational Perspective. Cases and controversies. Filadelfia: Penn Press, 2014. p. 347

54 SIEGEL, Reva B. Sex equality Arguments for Reproductive Rights: Their Critical Basis and Evolving Constitutional Expression. Emory Law Journal, vol. 56, n. 4, p. 833-834, 2007; MACKINNON, Catharine. Reflections on Sex Equality Under Law. Yale Law Journal, New Haven, vol. 100, n. 4, p. 1282, 1991.

55 OKIN, Susan Moller. Gênero, o público e o privado. Revista Estudos Feministas, Florianópolis, vol.16, n.2, p. 305-332, may/aug. 2008; KARST, Kenneth L. The Supreme Court, 1976 Term - Foreword: Equal Citizenship Under Fourteenth Amendment. Harvard Law Review, vol. 91, n. 1, p. 57-59, 1977.
} 
which we live, where, in general, women face a situation of subordination ${ }^{56}$, greatly influenced by intersections with race, class and sexuality ${ }^{57}$. In this context, the subordination situation is maintained because the existing power networks in society act in a superimposed manner, producing institutions, practices, norms and discourses that, at the same time, reflect power asymmetries and reproduce them ${ }^{58}$. Law is seen as one of these discourses and the prohibition of abortion as one of its mechanisms of subordination.

In view of the difference of structure of the two ways of arguing (equality as opposed to difference of treatment/equality as opposed to subordination), the most common conceptualizations of the equality principle in Brazil is not able to deal with cases such as the abortion issue. That because it can only deal with difference of treatment between groups and not with situations in which the practice is not necessarily discriminatory, but perpetuates subordination nonetheless. The argument pro-decriminalization that is based on its subordination potential would demand a conceptualization of equality that recognize not only individuals who suffer, but groups that face a subordinate status ${ }^{59}$.

In fact, it is possible to speculate that the prevalence of this narrow conception of equality has played a role in how the actors analyzed decided to formulate the abortion issue. There are a variety of reasons that can explain why actors frame their claims and decide to act in a certain way. Among others, choices are formulated according to the normative opportunity structure, which involve prejudices prevalent in the social context that make certain "strategies and tactics more or less likely to succeed"60. However, the mismatch between the formulation of the equality argument and the presentation of equality ideas might be the result of a narrow legal conception of what an equality argument can look like.

\subsection{The anti-subordination formulation: towards a new window for action}

56 MACKINNON, Catharine. Difference and dominance: on sex discrimination. In: MACKINNON, Catharine. Feminism Unmodified: Discourses on Life and Law. Cambridge: Harvard University Press, 1987. p. 32.

57 CRENSHAW, Kimberle. Mapping the Margins: Intersectionality, Identity Politics, and Violence Against Women of Color. Stanford Law Review, Palo Alto, vol. 43, n. 6, p. 1241 - 1299, jul. 1991.

58 BARATTA, Alessandro. O paradigma do gênero: Da questão criminal à questão humana. In. DE CAMPOS, Carmen Hein. Criminologia e feminismo. Porto Alegre: Editora Sulina, 1999, p. 41; SLAUGHTER, M.M. The legal construction of "Mother". In: FINEMAN, Martha; KARPIN, Isabel (Orgs.) Mothers in law: Feminist theory and the legal regulation of motherhood. Nova York: Columbia University Press, 1995, p. 77.

59 MOREIRA, Adilson José. Pensando como um negro: ensaio de hermenêutica jurídica. 1 ed. São Paulo: Editora Contracorrente, 2019. p. 253.

60 GLOPPEN, Siri. Conceptualizing Lawfare: A Typology \& Theoretical Framework. Center of Law and Social Transformation Pape, Bergen, 2018. Available at:<https://www.academia.edu/35608212/Conceptualizing Lawfare_A_Typology_and_Theoretical_Framwork>. 
Independently of the challenge presented above, that it - that the common understanding of equality as an issue of difference of treatment poses a challenge for those arguing that abortion is a violation of equality in a different way - formulating an anti-subordination argument also open a new window of opportunity legally-wise.

In the Initial Petition of ADPF 442, the claimant argues that the case should be seen as the next step in a case law line that involves reproduction related cases. The first being the case in which the Supreme Court decided that researches involving embryos was compatible with the Constitution, as life was not an absolute right and as the existence of a human being in development was not enough for the presumption of fundamental rights - ADI 3.510. The second being ADPF 54, where the Supreme Court, according to the ADPF 442 claimant, reaffirmed the idea that there are no absolute rights in the Brazilian legal system. And the third one being Habeas Corpus 124.306 where some of the Justices "interpreted the abortion issue as a reproductive decision morally reasonable for women, which criminalizing violates fundamental rights" ${ }^{\prime 61}$.

Looking at ADPF 442 as the teleological end of the chain constructed by other reproductive rights cases is one way of looking at abortion. However, the formulation of an anti-subordination argument could also be a strong way of arguing, if one considers the Supreme Court case law regarding equality as legal stock.

That, because the Supreme Court have decided an important case, where an anti-subordination approach is hinted in some of the individual votes: ADPF 186, a case involving racial affirmative action for universities. In this case, the Supreme Court have worked with the idea that black people have historically faced a subordinated status in Brazil and, therefore, affirmative actions were not only compatible with the Constitution, but were also a necessary means for overcoming subordination. This view was expressed, for instance, in the prevailing opinion:

[a]nother aspect of this discussion derives from the fact that affirmative action programs build upon the existing race consciousness within society with the final aim of eliminating it. In other words, the ultimate goal of these programs is to put an end to what was the initial social problem, i.e., the general subjective feeling of belonging to a particular race or being discriminated against because of one's membership in a group. In societies that have experienced slavery, repression, and prejudice, a fact responsible for the reproduction of derogatory images of certain racial groups, the legal guarantee of mere formal equality conceals differences between people, which helps to perpetuate the inequalities that exist between them. It is common knowledge that the small number of black and brown individuals performing relevant functions in the public and private

61 Initial petition, at 28 . 
spheres results from historical discrimination of successive generations, although I most cases in hidden or implied way ${ }^{62}$

The articulation of equality advanced by the Justice is a group-oriented equal protection perspective ${ }^{63}$. If one looks at the abortion issue as a liberty issue, as a health issue or a difference of treatment issue, it is not possible to notice the similarities between the affirmative action cases and the abortion issue. However, if one constructs the abortion issue as an equality as anti-subordination issue, the similarity becomes clear and it becomes possible to mobilize this line of case law as a legal stock.

This argument is yet to be further developed. However, it offers a strong new legal opportunity path for arguing for the decriminalization of abortion in Brazil. Actually, not only would it offer a new normative structure, but it would allow pro-decriminalization advocates to think about which court track record the abortion issue should be contributing to. The abortion issue can be a step in the reproductive-rights case law. But, it could also be a step in reinforcing the equality jurisprudence.

\section{CONCLUSIONS}

In our mapping we have identified three different ways of mobilizing the equality principle in the case of abortion: violation of equality for discriminatory treatment between women from different backgrounds, violation of equality for discriminatory treatment between women and men and violation of equality for the perpetuation of subordination (or, equality as anti-subordination). Also, stands out the fact that the very ideas that underlie the anti-subordination formulation are present in the many of the manifestations - the initial petition included - without being translated into rights or principle arguments.

In view of the results, we lay some comments on the limits and potentials of the formulation of equality as anti-subordination in the case of abortion in view available legal stock in the Brazilian legal opportunity structure, having in mind the existing conceptualizations of the equality principle and the case law established by the courts.

In what regards the limits, we argue that the most common conceptualizations of the equality principle in Brazil is not able to deal with cases such as the abortion issue. That because it can only deal with difference of treatment between groups and not with situations in which the practice is not necessarily discriminatory, but perpetuates subordination nonetheless. We claim that the non-translation of ideas of equality of

\footnotetext{
62 Quote from ADPF 186, quoted and translated by MOREIRA, Adilson José. Discourses of Citizenship in American and Brazilian Affirmative Action Court Decisions. American Journal of Comparative Law, [s.l.], vol. 64, n. 2, p. 492, 2016.

63 MOREIRA, Adilson José. Discourses of Citizenship in American and Brazilian Affirmative Action Court Decisions. American Journal of Comparative Law, [s.I.], vol. 64, n. 2, p. 492, 2016.
} 
anti-subordination into principled arguments could be an indicative of this limit posed by a narrow understanding of equality that permeates the Brazilian legal debate. In what regards the potentials, we argue that the formulation of an equality argument in the model of anti-subordination could be a strong way of arguing before the Supreme Court. That, because the Supreme Court have decided an important case in the basis of an anti-subordination approach: the affirmative action cases related to racial quotas for universities.

\section{REFERENCES}

ANDERSEN, Ellen Ann. Out of the Closets and Into the Courts: Legal Opportunity Structure and Gay Rights Litigation. Ann Arbor: University of Michigan Press, 2005.

BALKIN, Jack M. What Roe v. Wade Should Have Said: The Nation's Top Legal Experts Rewrite America's Most Controversial Decision. New York: University Press, 2005.

BARATTA, Alessandro. O paradigma do gênero: Da questão criminal à questão humana. In. DE CAMPOS, Carmen Hein. Criminologia e feminismo. Porto Alegre: Editora Sulina, 1999.

BARSTED, Leila de Andrade Linhares. Legalização e descriminalização do aborto no Brasil: 10 anos de luta feminista. Revista Estudos Feministas, Florianópolis, v. 0, n. 0, p. 104-130, 1992.

BRAZIL. Brazilian Supreme Court. Claim of Non-Compliance with Fundamental Precept $\mathrm{n}^{\circ} 186$. Judge-Rapporteur: Ricardo Levandowsky, Brasília, DF, Oct. 17,2014.

BRAZIL. Brazilian Supreme Court. Claim of Non Compliance with Fundamental Precept $\mathbf{n}^{\circ} \mathbf{4 4 2}$. Judge-Rapporteur: Justice Rosa Weber. Brasília, DF, Mar. 3, 2017.

BRAZIL. Brazilian Supreme Court. Sentence. Claim of Non Compliance with Fundamental Precept $\mathbf{n}^{\circ}$ 54. Judge-Rapporteur: Justice Marco Aurélio. Brasília, DF, Apr. 30, 2013. Accessed on: 16 Mar. 2018.

BRAZIL. Brazilian Supreme Court. Sentence. Direct Action of Unconstitutionality n $\mathbf{n}^{\mathbf{3}}$ 3.510/DF. Judge-Rapporteur: Justice Ayres Brito. Brasília, DF, May 28, 2010. Accessed on: 19 Mar. 2018.

BRAZIL. Brazilian Supreme Court. Sentence. Habeas Corpus n 124.306/RJ. Judge-Rapporteur: Justice Marco Aurélio. Brasília, DF, Mar. 17, 2017. Accessed on: 16 Mar. 2018.

BRAZIL. Constituição da República Federativa do Brasil, of October 5, 1988. Diário Oficial da União, Brasília, DF, Oct. 5, 1988. Available at: <http://www.planalto.gov.br/ccivil_03/constituicao/ constituicao.htm>.

BRAZIL. Decreto-lei n. 2.848, de 7 de dezembro de 1940. Código Penal. Diário Oficial da União, Rio de Janeiro, RJ, Dec. 7, 1940. Available at:<http://www.planalto.gov.br/ccivil_03/decreto-lei/ Del2848compilado.htm>.Accessed on: 19 Mar. 2018. 
BRAZIL. Lei n. 9.868, of November 10, 1999. Dispõe sobre o processo e julgamento da ação direta de inconstitucionalidade e da ação declaratória de constitucionalidade perante o Supremo Tribunal Federal. Diário Oficial da União, Brasília, DF, Nov. 10, 1999. Available at: <http://www. planalto.gov.br/ccivil_03/leis/l9868.htm>. Accessed on: 20 Mar. 2018.

BRAZIL. Lei n. 9.882, of December 3, 1999. Dispõe sobre o processo e julgamento da argüição de descumprimento de preceito fundamental, nos termos do $\S 1^{\circ}$ do art. 102 da Constituição Federal. Diário Oficial da União, Brasília, DF, Dec. 3, 1999. Available at:<http://www.planalto.gov.br/ ccivil_03/Leis/L9882.htm>. Accessed on: 20 mar. 2018.

BURRIS, Scott. Stigma and the law. The Lancet, [s.I.], vol. 367, p. 529-531, 2006.

CASE, Rhonda Evans; TERRI, Givens. Re-engineering Legal Opportunity Structures in the European Union? The Starting Line Group and the Politics of the Racial Equality Directive. Journal of Common Market Studies, [s.I.], vol. 48, n. 2., p. 221-241, mar. 2010.

COOK, Rebecca J. Stigmatized Meanings of Criminal Abortion Law. In: COOK, Rebecca J.; ERDMAN, Joanna N.; DICKENS, Bernard M. Abortion Law in Transnational Perspective. Cases and controversies. Filadelfia: Penn Press, 2014.

CRENSHAW, Kimberle. Mapping the Margins: Intersectionality, Identity Politics, and Violence Against Women of Color. Stanford Law Review, Palo Alto, vol. 43, n. 6, p. 1241 - 1299, jul. 1991.

GINSBURG, Ruth Bader. Some thoughts on Autonomy and Equality in Relation to Roe v. Wade. North Carolina Law Review, Chapel Hill, vol. 63, n. 2, p. 375-386, 1985. Available at:<https:// scholarship.law.unc.edu/cgi/viewcontent.cgi? referer=\&httpsredir=1\&article=2961\&context=nclr>. Retrieved Oct. 25, 2019.

GLOPPEN, Siri. Conceptualizing Lawfare: A Typology \& Theoretical Framework. Center of Law and Social Transformation Paper, Bergen, 2018. Available at:<https://www.academia. edu/35608212/Conceptualizing_Lawfare_A_Typology_and_Theoretical_Framwork $>$.

HILSON, Chris "New Social Movements: The Role of Legal Opportunity". Journal of European Public Policy, [s.l.], vol. 9, n.2, p. 238-255, 2002.

KARST, Kenneth L. The Supreme Court, 1976 Term - Foreword: Equal Citizenship Under Fourteenth Amendment. Harvard Law Review, vol. 91, n. 1, p. 57-59, 1977.

LAW, Sylvia A. Rethinking Sex and the Constitution. University of Pennsylvania Law Review, Filadelfia, vol. 132, p. 132, 1984.

LEAL, Fernando; HERDY, Rachel; MASSADAS, Julia. Uma década de audiências públicas no Supremo Tribunal Federal (2007-2017). Revista de Investigações Constitucionais, Curitiba, vol.5, n.1, p. 334, jan./apr. 2018. Available at: <https://revistas.ufpr.br/rinc/article/view/56328>. Retrieved Oct. 25, 2019. 
MACHADO, Marta; MACIEL, Debora. The Battle Over Abortion Rights in Brazil's State Arenas, 1995-2006. Health and Human Rights Journal. Boston, vol. 19, n. 1, Jun. 2, 2017. Available at: <https://www.hhrjournal.org/2017/06/the-battle-over-abortion-rights-in-brazils-state-arenas-1995-2006/ $\geq$. Retrieved Oct. 25, 2019.

MACHADO, Marta Rodriguez de Assis; COOK, Rebecca J. Constitutionalizing abortion in Brazil. Revista de Investigações Constitucionais, Curitiba, vol. 5, n. 3, p. 185-231, set./dez. 2018. Available at: <https://revistas.ufpr.br/rinc/article/view/60973/37524 . Retrieved Oct. 25, 2019.

MACKINNON, Catharine. Abortion: On Public and Private. In: MACKINNON, Catharine. Toward a Feminist Theory of the State. Cambridge: Harvard University Press, 1989.

MACKINNON, Catharine. Difference and dominance: on sex discrimination. In: MACKINNON, Catharine. Feminism Unmodified: Discourses on Life and Law. Cambridge: Harvard University Press, 1987

MACKINNON, Catharine. Reflections on Sex Equality Under Law. Yale Law Journal, New Haven, vol. 100, n. 4, p. 1282, 1991.

MOREIRA, Adilson José. Discourses of Citizenship in American and Brazilian Affirmative Action Court Decisions. American Journal of Comparative Law, [s.I.], vol. 64, n. 2, p. 492, 2016.

MOREIRA, Adilson José. Pensando como um negro: ensaio de hermenêutica jurídica. 1 ed. São Paulo: Editora Contracorrente, 2019.

OKIN, Susan Moller. Gênero, o público e o privado. Revista Estudos Feministas, Florianópolis, vol.16, n.2, p. 305-332, may/aug. 2008.

ROCHA, Carmen Lúcia Antunes. Ação afirmativa: o conteúdo democrático do princípio da igualdade jurídica. Revista de Informação Legislativa, Brasília, vol. 33, n. 131, jul./sep. 1996.

SABADELL, Ana Lucia; DIMOULIS, Dimitri. Constitucionalidade, moralidade e tratamento penal do aborto. In: SARLET, Ingo; LEITE, George Salomão. (Org.). Direitos fundamentais e biotecnologia. 1ed. São Paulo: Método, 2008. p. 325-34.

SARLET, Ingo Wolfgang. A eficácia dos direitos fundamentais: uma teoria geral dos direitos fundamentais na perspectiva constitucional. 10. ed. Porto Alegre: Livraria do Advogado Editora, 2011. SARMENTO, Daniel. Livres e iguais: estudos de direito constitucional. 2. ed. Rio de Janeiro: Lumen Juris, 2010.

SIEGEL, Reva B. Reasoning from the body: a historical perspective on abortion regulation and questions of equal protection. Stanford Law Review, Palo Alto, vol. 44, n.2, p. 261-382, jan. 1992.

SIEGEL, Reva B. Sex equality Arguments for Reproductive Rights: Their Critical Basis and Evolving Constitutional Expression. Emory Law Journal, vol. 56, n. 4, p. 815-842, 2007. 
SIEGEL, Neil S.; SIEGEL, Reva B. Equality Arguments for Abortion Rights. UCLA Law Review Discourse, [s.l], vol. 160, n. 60, p. 160-170, 2013.

SIERRA, Isabel Cristina Jaramillo. Introducción. In: BERGALLO, Paola; SIERRA, Isabel Cristina Jaramillo; VAGGIONE, Juan Marcos. El aborto em América Latina. Estrategias jurídicas para luchar por su legalización y enfrentar las resistencias conservadoras. Buenos Aires: Siglo XXI Editores Argentina, 2018.

SILVA, José Afonso da. Curso de direito constitucional positivo. 32 ed. São Paulo: Malheiros, 2009.

SLAUGHTER, M.M. The legal construction of "Mother". In: FINEMAN, Martha; KARPIN, Isabel (Orgs.) Mothers in law: Feminist theory and the legal regulation of motherhood. Nova York: Columbia University Press, 1995.

TRIBE, Laurence H. American Constitutional Law. 2. ed. [s.l.]: Foundation Press, 1988. 